\title{
Peningkatan Kesadaran Masyarakat terhadap Kerusakan Bangunan dan Lingkungan Pasca Gempa, Tsunami dan Likuifaksi di Palu Sulawesi Tengah
}

\author{
Hutabarat, L.E1, Simanjuntak, $\mathrm{P}^{2}$, Tampubolon, $\mathrm{S}^{3}$ \\ Universitas Kristen Indonesia, Jakarta, Indonesia ${ }^{1,2,3}$ \\ E-mail: Lolom.Hutabarat@uki.ac.id; Pinondang.Simanjuntak@uki.ac.id; \\ Sudarno.Tampubolon@uki.ac.id;
}

\begin{abstract}
Abstrak
Kejadian Gempa Palu pada tanggal 28 September 2018 telah menimbulkan korban jiwa dan kerugian besar dengan kerusakan pada infrastruktur dan bangunan di tiga daerah Palu, Sigi dan Donggala. Tragedi ini diakibatkan oleh magnitudo gempa yang sangat kuat M 7.4 diikuti oleh tsunami dan peristiwa likuifaksi yang sangat dahsyat. Karena itulah perlu dilakukan survey berikut assesmen data kerusakan bangunan yang terjadi di Palu sekaligus penyuluhan terkait teknis bangunan rumah tinggal tahan gempa. Sesuai hasil survei, likuifaksi terjadi di tiga lokasi yaitu Petobo, Balaroa dan Sigi. Sedangkan tsunami terjadi di pesisir pantai Donggala akibat terjadinya keruntuhan massa tanah yang besar saat terjadi likuifaksi. Beberapa bangunan dan infrastruktur yang mengalami kerusakan disebabkan oleh sifat teknis bangunan yang tidak mampu menahan beban gempa. Secara umum para warga warga Palu dan Sekitarnya di Sulawesi Tengah belum sepenuhnya memahami konsep bangunan tahan gempa khususnya untuk rumah tinggal sederhana.
\end{abstract}

Kata Kunci: likuifaksi, tsunami, kerusakan bangunan, survei, asessemen

\begin{abstract}
The Palu earthquake on 28 September 2018 caused heavy casualties and losses with damage to infrastructure and buildings in three areas which are Palu, Sigi and Donggala. This tragedy was an impact of a very strong earthquake magnitude 7.4 followed by a tsunami and a very terrible liquefaction. It was necessary to conduct a survey following the assessment of building damage data that occurred in Palu as well as technical assistance to understand the earthquake resistant residential buildings concept. Based on the survey results, liquefaction occurred in three locations namely Petobo, Balaroa and Sigi. While the tsunami occurred on the coast of Donggala due to large land mass collapse during liquefaction. Some buildings and infrastructure that were damaged due to the lack of technical requirement of the earthquake loads resistancy building. In general, the society of Palu and the surrounding areas were not having adequate knowledable for the concept of earthquake resistant buildings, especially for simple residential buildings.
\end{abstract}

Keywords:. liquefaction, tsunami, building damage, surveys, assessments

\section{PENDAHULUAN}

Belum lama gempa telah mengguncang pulau Lombok, Nusa Tenggara Barat (NTB) pada tanggal tanggal 29 Juli 2018 dengan skala 6,4 M diikuti gempa susulan sampai 133 kali dengan skala $7 \mathrm{M}$, kemudian terjadi lagi guncangan Gempa di Palu Sulawesi Tengah tanggal 28 September 2018 yang mencapai $7.4 \mathrm{M}$ sehingga memporak porandakan bangunan di Palu, Donggala, Sigi dan Balaroa. bahkan akibat gempa tersebut terasa sampai wilayah Bali dan sekitarnya. Bencana alam yang terjadi kali ini merupakan peristiwa yang sangat khusus karena gempa juga diikuti dengan tsunami dan liquifasi (pergerakan tanah) sehingga korban jiwa mencapai 2.256 
serta 1.309 hilang menurut data BNPB (21/10/2018). Selain itu bangunan dan infrastruktur yang juga hancur atau rusak akibat bencana diantaranya 68.451 unit rumah, 327 unit rumah ibadah, 265 unit sekolah, 78 unit perkantoran, 362 unit toko, 168 titik jalan rusak/retak serta 7 unit jembatan hancur (kaltim tribunnews, 21/10/2018). Peristiwa ini meninggalkan duka yang sangat mendalam bukan saja bagi masyarakat Indonesia tapi juga bagi dunia. Kejadian gempa yang diikuti oleh peristiwa likuifaksi bukanlah sesuatu hal yang sering terjadi baik di Indonesia ataupun di belahan dunia lain.

Akibat Gempa tersebut banyak bangunan rusak bahkan runtuh di Palu dan di Donggala serta beberapa bangunan tenggelam akibat adanya Likuifaksi. Beberapa Bangunan bertingkat seperti bangunan Hotel Roa roa rubuh total. Bandar Udara juga rusak, sehingga tdak bisa beroperasi untuk beberapa lama. Pada lokasi episentrum gempa, mengalami kerusakan terparah. Ribuan rumah rusak Kerusakan ini diperparah oleh tidak adanya peraturan bangunan dan pengetahuan teknis tentang ketahanan terhadap gempa serta kemampuan ekonomi yang rendah.

Berdasarkan fakta tersebut diatas maka dpat diketahui bahwa Pemahaman masyarakat tentang menghindari akibat Gempa belum melekat pada mereka. Karena itu sudah saatnya masyarakat dilengkapi pengetahuan menghindari resiko akibat Gempa. Salah satunya adalah cara membuat bangunan tahan gempa. Hal ini adalah sudah menjadi kebutuhan penting di Palu dan sekitarnya Dengan pemahaman dan pengertian bangunan tahan gempa yang benar dengan sendirinya masyarakat akan lebih trampil untuk membuat bangunan tahan gempa untuk keperluan mereka.

Karena itu FT UKI melihat penting untuk mengirimkan Tim yang di koordinasikan oleh Pusat Studi Kebencanaan Program Studi Teknik Sipil FT UKI untuk bekerja sama dengan Prodi Teknik Sipil Universitas Tadulako dan Pemda Setempat melakukan Survey data kerusakan bangunan yang terjadi di Palu serta melakukan asesmen tingkat kerusakan pada beberapa bangunan pasca gempa sekaligus juga memberikan penyuluhan terkait teknis bangunan rumah tinggal tahan gempa bagi warga gereja HKBP Palu.

\section{METODE}

Berdasarkan hal tersebut diatas maka dengan adanya kejadian gempa Palu, Prodi sipil FT UKI merencanakan kegiatan Pengabdian Kepada Masyarakat ini dengan cara:

a. Membantu masyarakat korban gempa di Palu dan sekitarnya untuk memastikan tingkat kerusakan yang terjadi pada bangunan mereka yang mengalami kerusakan akibat gempa sehingga dapat mengetahui tingkat 
kelayakan bangunan mereka dengan baik, secara khusus di lingkungan warga gereja HKBP Palu.

b. Membantu masyarakat untuk memiliki pemahaman yang utuh tentang pentingnya pembuatan bangunan tahan gempa di Palu

c. Memperoleh data hasil survey sebagai bahan awal untuk penelitian bangunan tahan gempa dalam rangka memberikan rekomendasi kepada Pemerintah Daerah tentang tipe dan karakteristik bangunan tahan gempa yang tepat di Palu.

d. Memberikan masukan kepada Pemda Palu perkiraan kerusakan bangunan akibat gempa dari hasil survei yang dilakukan di 3 lokasi yang menjadi korban gempa

e. Memberdayakan Pusat Studi Kebencanaan FT UKI bekerja sama dengan Prodi Teknik Sipil Universitas Tadulako dalam rangka memberikan keterampilan kepada masyarakat Palu untuk membuat bangunan rumah tinggal yang bisa mengurangi resiko terhadap gempa

Adapun penyuluhan yang telah dilaksanakan di gereja HKPB Palu pada tanggal 21 Oktober 2018 bertempat di gedung gereja HKBP Palu Jl. Gereja No.36 Tanjung Maningbaya Palu yang diikuti oleh 38 peserta terdiri dari 21 pria dan 17 wanita. Gereja ini juga merupakan salah satu shelter untuk tempat pengungsian korban pas gempa Palu dengan didirikannya tenda pengungsian di halaman gereja HKBP Palu yang menampung warga jemaat yang rumahnya mengalami kerusakan akibat gempa. Selain itu juga faktor ketakutan akan terjadinya likuifaksi menyebabkan warga jemaat lebih memilih untuk berada di tenda pengungsian dibandingkan dengan tinggal di dalam rumah.

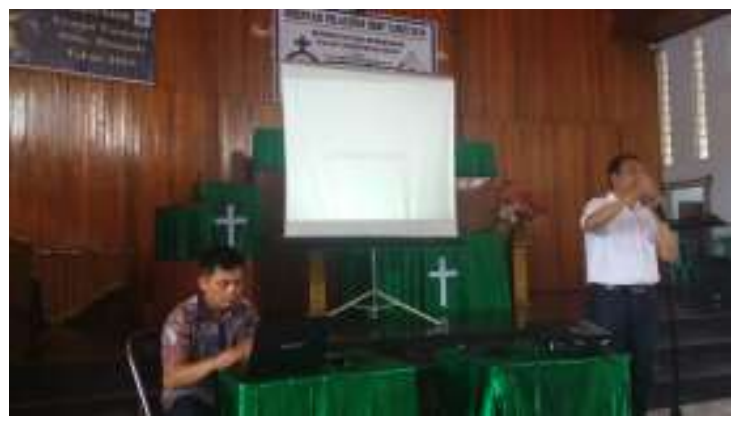

Gambar 1. Penyuluhan bangunan tahan gempa

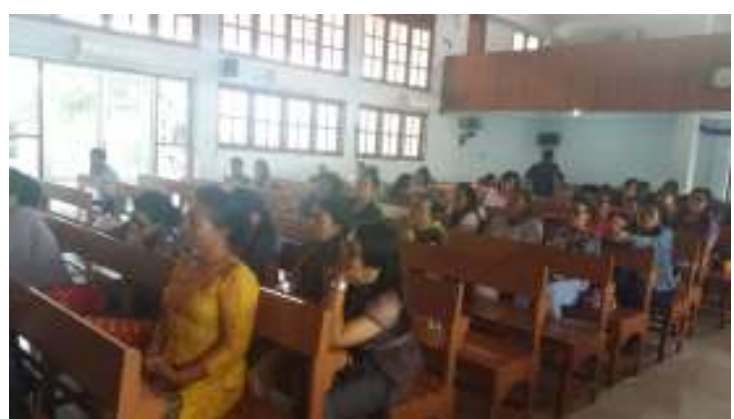

Gambar 2. Peserta Penyuluhan bangunan tahan gempa

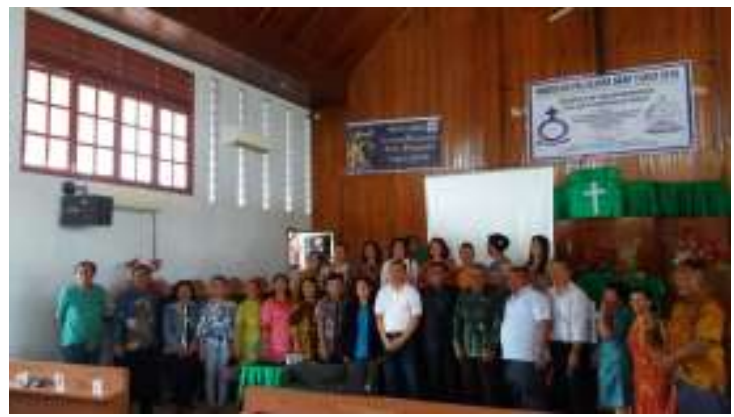

Gambar 3. Foto bersama jemaat HKBP Palu 


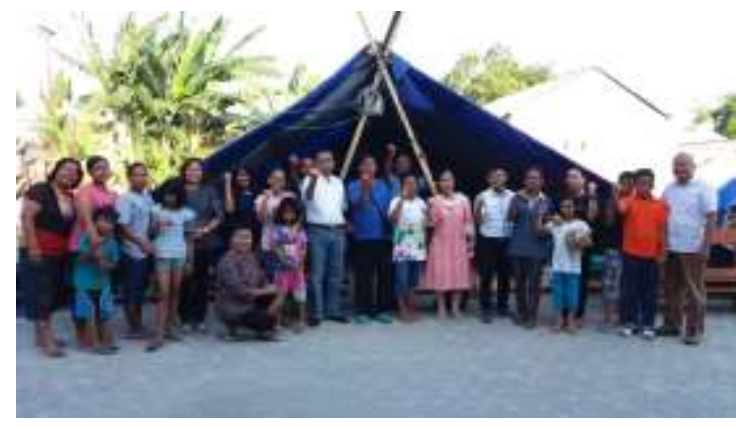

Gambar 4. Tenda pengungsian korban gempa di HKBP Palu

\section{HASIL DAN PEMBAHASAN}

Selama kegiatan PKM berlangsung dari tanggal 21 s.d 26 Oktober 2018, telah dilakukan survei serta asessemen juga dilakukan terhadap beberapa rumah warga jemaat rusak akibat gempa baik yang tingkat kerusakan ringan sampai dengan berat. Hal tersebut dirasakan sangat membantu bagi pemilik rumah yang secara psikologis masih sangat ketakutan jika sewaktu-waktu terjadi gempa susulan maka akan sangat membahayakan dengan kondisi rumahnya saat ini.Dengan demikian masyarakat perlu memahami pengetahuan tentang penyebab gempa yang terjadi di Palu terkait sesar PaluKoro berikut masalah goeteknis dan akibat liquifaksi yang ditimbulkannya serta timbulnya gelombang tsunami di pesisir pantai akibat gempa yang terjadi.

\section{(a) Kegempaan di Sulawesi dan Sesar Palu Koro}

Pulau Sulawesi merupakan pertemuan dari tiga lempeng besar yang bergerak dalam arah yang berlawanan satu dengan lainnya yaitu Lempeng Indo-Australia yang bergerak ke utara, Lempeng Pasifik yang bergerak ke barat dan Lempeng Eurasia yang bergerak ke arah selatan-tenggara (Juwanto D., 2013). Ketika terjadi pergerakan pada salah satu sesar tersebut maka akan terjadi subduksi. Seismisitas di Sulawesi berkaitan dengan subduksi di Utara Sulawesi, sesar Palu Koro, Sesar Matano dan subduksi Lempeng laut Maluku di Timur. Sesar Palu Koro adalah sesar terpanjang di pulau Sulawesi yang menjadi struktur utara terbentang mulai Sulawesi Tengah hingga Selat Karimata (Pusat Studi Gempa Nasional, 2017). Aktifitas Sesar Palu Koro inilah yang seringkali menyebabkan terjadinya gempa. Topografi wilayah Palu dan sekitarnya berada pada suatu lembah dengan ketinggian sampai dengan $500 \mathrm{~m}$ di atas permukaan laut. Wilayah bagian barat yang lebih tinggi memiliki potensi rawan terhadap keruntuhan lereng. Sedangkan bagian yang merupakan pesisir pantai dan pinggir sungai Palu juga rawan terhadap bencana liquifaksi dan tsunami (Ramadhani S, 2011).

Peristiwa gempa sudah seringkali terjadi di Palu sejak sekitar lebih dari 100 tahun sebelumnya. Tercatat pada 1907, retakan sesar yang berarah tegak lurus Sesar PaluKoro sekitar wilayah Kulawi hingga Lindu menyebabkan terjadi gempabumi. Dua tahun berikutnya, terjadi gempabumi dengan kekuatan lebih besar yang menghancurkan seluruh wilayah itu. Berikutnya pada tahun 1927 bahkan terjadi gempa yang diikuti tsunami, dilanjutkan gempa bumi di 
sepanjang pantai kampung Mamboro pantai barat Kabupaten Donggala tahun 1938 menyapu bersih seluruh rumah dan pohon kelapa di wilayah tersebut. Disusul gempa dahsyat dengan magnitudo 7,3 dan pusat di Laut Sulawesi pada tanggal 10 Agustus 1968 menghancurkan rumah-rumah di sepanjang pesisir Tambu dengan tinggi gelombang tsunami 8-10 m serta menyapu bersih seluruh pantai sejauh $300 \mathrm{~m}$. Gempa susulan dengan magnitudo 7,4 menghasilkan tsunami yang menenggelamkan pulau Tuguan. Pada tahun 2012 karakteristik gempa yang hampir sama kembali terjadi. Secara geologis, Sigi, Donggala dan Palu adalah lintasan dari Sesar Palu Koro yang membentang sepanjang arah utara selatan dengan panjang $500 \mathrm{~km}$ secara keseluruhan dimana setengahnya berada di daratan mulai dari teluk Palu sampai utara teluk Bone. Dengan adanya pertemuan tiga lempeng tektonik utama diatas, wilayah ini rawan akan bencana alam yang diakibatkan oleh pergerakan lempeng-lempeng tersebut sehingga mendorong pergerakan Sesar Geser Palu Koro. Inilah penyebab gempabumi dengan kekuatan 7,4 M yang meluluhlantakan wilayah pesisir Teluk Palu pada 28 September 2018. Goncangan gempabumi itu dirasakan meliputi wilayah Kabupaten Donggala, Kota Palu, Kabupaten Parigi Moutong, Kabupaten Sigi, Kabupaten Poso, Kabupaten Tolitoli, Kabupaten Mamuju bahkan hingga Kota Samarinda, Kota Balikpapan, dan Kota Makassar ((Badan Geologi Kementrian ESDM,
2018). Dalam periode 2009-2015 gempa terdalam yang berkaitan dengan Sesar Matano adalah $50 \mathrm{~km}$ dan untuk Sesar Palu Koro adalah $40 \mathrm{~km}$ (Pusat Studi Gempa Nasional, 2017).

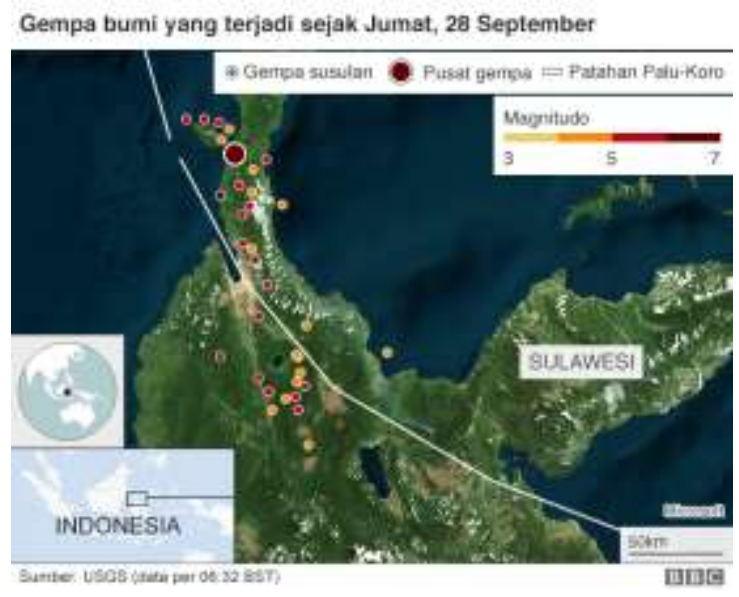

Gambar 5. Sesar Palu Koro (sumber USGS)

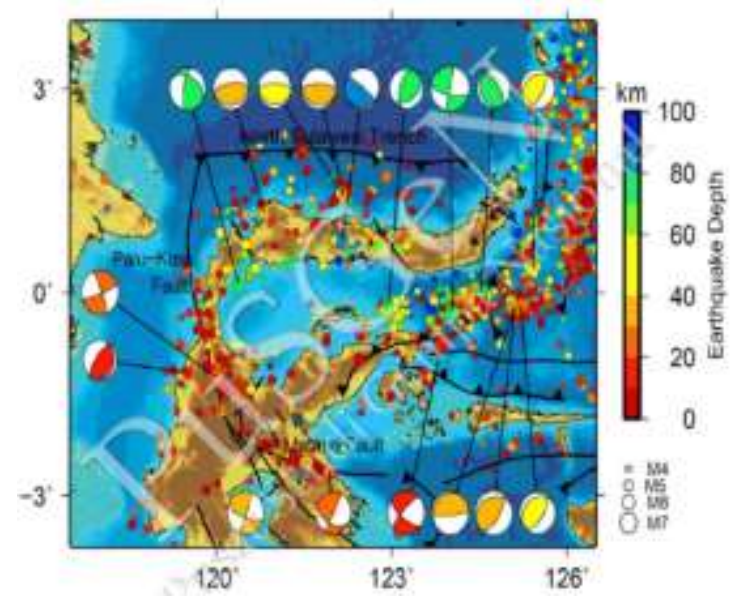

Gambar 6. Episenter gempa Sulawesi

(sumber Pusat Studi Gempa Nasional, 2017)

\section{(b)Fenomena Liquifaksi di Palu}

Peristiwa likuifaksi di Palu mengundang banyak perhatian dari para peneliti karena merupakan kejadian yang termasuk langka dunia. Khususnya karena liqufaksi tersebut bersifat masif dan telah menimbulkan tingkat kerusakan yang sangat tinggi serta korban jiwa yang 
sangat banyak. Untuk itu perlu diberikan pemahaman apa yang disebut dengan likuifaksi. Fenomena likuifaksi menurut sumber Wikipedia mulai menarik para peneliti setelah gempa bumi Niigata di Jepang tahun 1964 dan Alaska tahun 1964. Pencairan tanah ini juga menjadi faktor utama kerusakan di Distrik Marina San Fransisko setelah gempa bumi Loma Prieta tahun 1989 dan di Pelabuhan Kobe akibat gempa bumi Hanshin tahun 1995. Pencairan terakhir yang mengakibatkan kerusakan besar menimpa perumahan di timur pinggiran kota dan kota satelit Christchurch, Selandia Baru setelah gempa bumi Canterbury 2010 dan 2011.

Pencairan tanah atau likuifaksi tanah (soil liquefaction) adalah fenomena yang terjadi ketika tanah yang jenuh air atau agak jenuh kehilangan kekuatan dan kekakuan akibat adanya peningkatan tegangan yang sangat besar secara tibatiba, misalnya getaran akibat gempa bumi dengan magnitude yang cukup besar atau perubahan tegangan lain secara mendadak, sehingga tanah yang padat berubah perilakunya menjadi seperti fluida atau cairan dan kehilangan kekuatan dukukungnya. Fenomena ini paling sering diamati pada tanah berpasir yang jenuh dan tidak padat (loose). Ini karena pasir lepas merupakan jenis tanah yang tidak memiliki ikatan antar butiran (cohesionless) serta memiliki kecenderungan untuk memampat ketika mengalami tegangan. Jika tanah jenuh dengan air, suatu kondisi yang sering terjadi ketika tanah berada di bawah permukaan air tanah atau permukaan laut, maka air mengisi kesenjangan di antara butir-butir tanah (rongga atau pori tanah). Sebagai respon terhadap tanah yang memampat, air ini meningkatkan tekanan dan mencoba untuk mengalir keluar dari tanah ke zona bertekanan rendah (biasanya ke atas menuju permukaan tanah). Tapi, jika peningkatan tegangan berlangsung cepat dan cukup besar, serta diulangi berkali-kali (contoh getaran gempa bumi dan gelombang badai), maka air tidak sempat mengalir keluar sesuai waktunya sebelum siklus pembebanan berikutnya terjadi.

Tekanan air pori ekses tersebut dapat bertambah melebihi tekanan kontak antara butir-butir tanah yang menjaga mereka tetap saling bersentuhan satu sama lain. Kontak antara butir-butir ini merupakan media pemindahan berat bangunan dan lapisan tanah di atas dari permukaan tanah ke lapisan tanah atau batuan pada lapisan yang lebih dalam. Hal ini menyebabkan tanah kehilangan semua kekuatannya (kemampuan untuk memindahkan tegangan geser) dan fenomena ini terlihat seperti mengalir menyerupai cairan maka disebut pencairan tanah (likuifaksi tanah). Kejadian likuifaksi di Palu merupakan penyebab utama kerusakan rumah dan infrastruktur di atasnya. Umumnya kejadian likuifaksi didahului oleh 
peristiawa yang disebut dengan sand boil atau naiknya lapisan pasir ke permukaan tanah.

(a) Naiknya Lapisan Pasir (Sand Boil)

Sand boil atau keluarnya pasir dari bawah permukaan tanah tidak selalu menyebabkan keruntuhan tanah tetapi mengindikasikan bahwa di bawah permukaan tanah terjadi likuifaksi. Hal ini terjadi karena air yang naik ke permukaan tanah akibat peningkatan tegangan air pori ekses tersebut membawa material pasir dari bawah. Air bertekanan tinggi yang muncul di lapisan permukaan tanah yang tidak mengalami likuifaksi dan membawa tanah sedimen untuk kemudian diendapkan seperti kerucut berkawah yang terbentuk dalam jumlah yang besar. Sehingga seringkali terjadi perpindahan secara lateral di bagian permukaan tanah.

\section{(b) Perpindahan Lateral (Lateral Spread)}

Perpindahan lateral (lateral spread) adalah pergerakan blok-blok tanah dalam arah lateral sebagai dampak dari likuifaksi yang terjadi karena tanah lapisan bawah kehilangan kekuatan gesernya. Perpindahan lateral merupakan hasil kombinasi akibat gaya gravitasi dan gayagaya inersia yang ditimbulkan oleh gempa pada lereng yang relatif landai. Tingkat kerusakan yang terjadi tergantung pada berapa jauh perpindahan lateral yang terjadi serta posisi bangunan dan infrastruktur yang ada di permukaan tanah. Peralihan lateral tersebut bisa mencapai beberapa meter seperti yang terjadi di Sigi dan Balaroa (Tim Peneliti Unpar, 2019). Di beberapa lokasi dimana tegangan geser pada lapisan tanah di permukaan justru selalu naik terhadap regangan geser ketika terjadi likuifaksi maka yang terjadi adalah cyclic mobility dan bukan lateral spread. Pada cyclic mobility semakin besar regangan geser maka tegangan geser juga semakin besar dan kondisi tanah makin kuat.

Deformasi yang ditimbulkan oleh cyclic mobility umumnya terbatas dan serupa dengan perpindahan lateral.

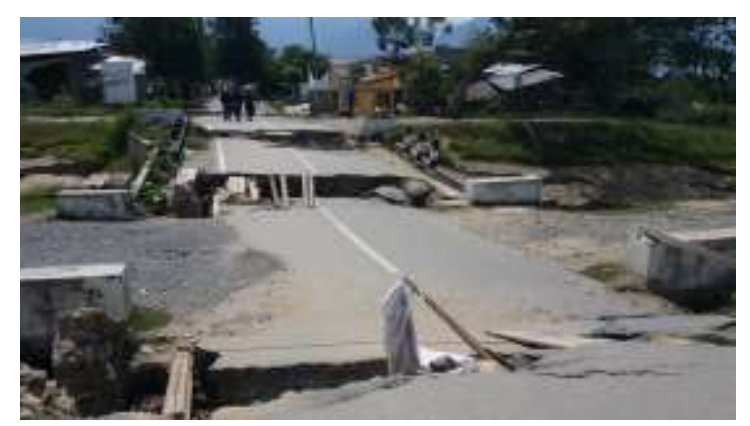

Gambar 7. Liquifaksi yang menghancurkan jalan di wilayah Sigi

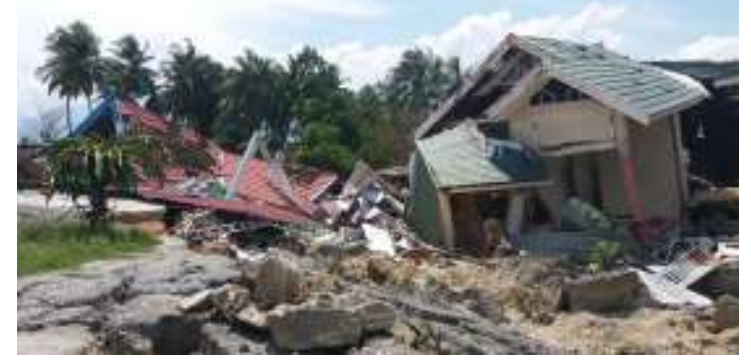

Gambar 8. Liquifaksi yang menunggangbalikkan rumah-rumah 


\section{Gambar 9. Peristiwa Liquifaksi menghancurkan pompa bensin}

\section{(c) Peristiwa Likuifaksi di Palu}

Survei yang dilakukan oleh tim PKM Prodi Teknik Sipil FT UKI menemukan di wilayah Balaroa terdapat lapisan pasir halus yang mendominasi wilayah tersebut. Kondisi ini memenuhi syarat untuk terjadinya likuifaksi akibat gempa yang terjadi dengan $\mathrm{M}=7,4$ (BMKG) yang berpusat $26 \mathrm{Km}$ dari Donggala. Gempa terjadi pada sesar Palu-Koro yang membentang utara-selatan di sepanjang tepi Teluk Palu sehingga menyebabkan terjadinya tsunami, longsor, likuifaksi dan perpindahan lateral (lateral spread). Wilyah Balaroa merupakan daerah yang mengalami likuifaksi terparah dibandingkan daerah yang lainnya.
Secara umum kondisi geologi regional kota Palu merupakan endapan alluvium dan deposit pantai. Endapan ini terdiri dari kerikil, pasir, lumpur, dan batu kapur karang. Endapan ini terbentuk di sungai dangkal, delta dan lingkungan laut. Berdasarkan peta geologi ( menunjukkan bahwa keberadaan lapisan alluvial yang ada di Palu cukup tebal. Hal ini menjadi faktor amplifikasi dan deamplikasi perambatan gelombang gempa. Ketebalan lapisan pasir yang ada sangat berpengaruh terhadap dampak likuifaksi ditambah dengan banyak kandungan air. Akuifer yang ada pada kota Palu bersifat dangkal karena terdapat lapisan pasir yang tebal.

Di daerah Petobo, di sebelah selatan bandara Palu, terlihat daerah tersebut mengalami hal yang sama dengan Balaroa. Perumahan yang ada didaerah ini tenggelam. Lumpur dengan volume sangat besar tenggelam dan menyeret kompleks perumahan di Petobo sehingga sebagian besar dari mereka menjadi seolah-olah tertelan masuk ke dalam bumi. Diperkirakan 744 unit rumah ada di sana. Untuk itu dibutuhkan tindak lanjut pasca gempa dan likuifaksi Palu agar bisa mereduksi kerusakan bangunan dan infrastruktur jika kejadian serupa berulang di masa mendatang

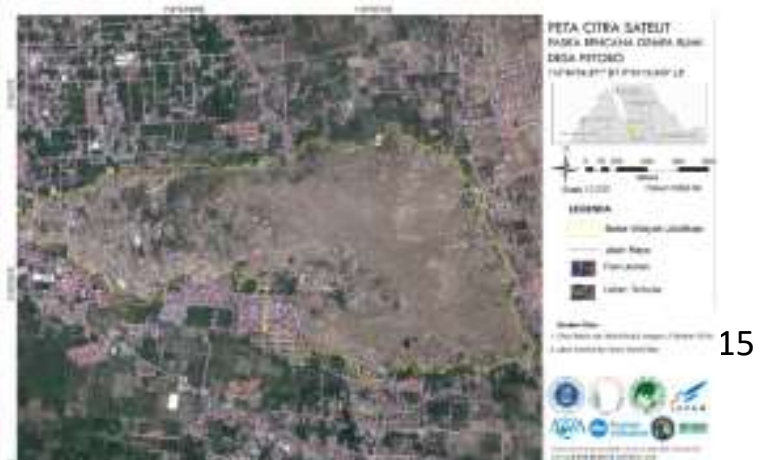


Gambar 10. Foto Udara Wilayah yang terkena Liquifaksi di Palu (Sumber: Lapan, Center for Remote Sensing ITB dan AIT

(d) Likuifaksi Mengalir

Pada struktur tanah dalam kondisi lepas (lereng alam dan lereng buatan) akan mengalami penurunan kuat geser yang cukup besar diikuti dengan regangan geser yang sangat besar saat peristiwa likuifaksi terjadi. Ketika tegangan geser yang terjadi di lapangan akibat gaya gravitasi dan beban bangunan di atasnya lebih besar dari kuat geser residual tanah saat terjadi likuifaksi maka tanah bisa mengalir sangat jauh. Syarat terjadinya likuifaksi adalah pada tanah pasiran (cohesionless) yang tidak banyak mengandung lempung. Likuifaksi mengalir dapat mengakibatkan keruntuhan fatal, yang dapat dicirikan dengan pergerakan yang besar dan cepat sehingga menyebabkan dampak kerusakan yang hebat sebagaimana yang terjadi di Sulawesi Tengah meliputi wilayah Palu, Balaroa, Petobo, dan Sigi

\section{Gambar 11. Liquifaksi di wilayah \\ Balaroa menenggelamkan perumahan sehingga hilang dari permukaan tanah}

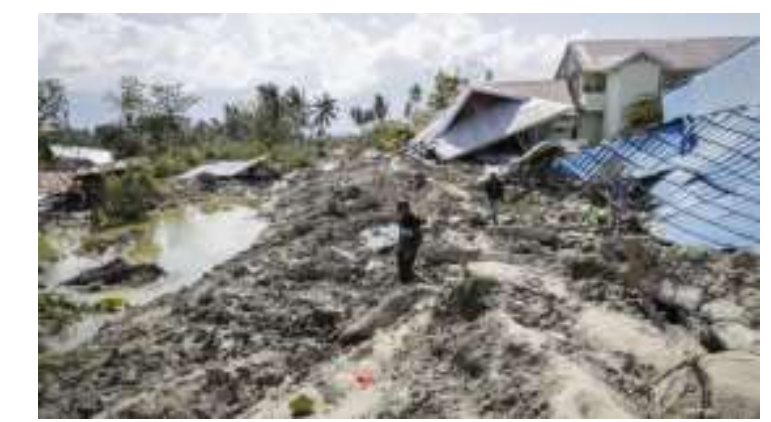

Gambar 12. Liquifaksi di wilayah Petobo yang tak kalah parahnya (Sumber: BBC News)

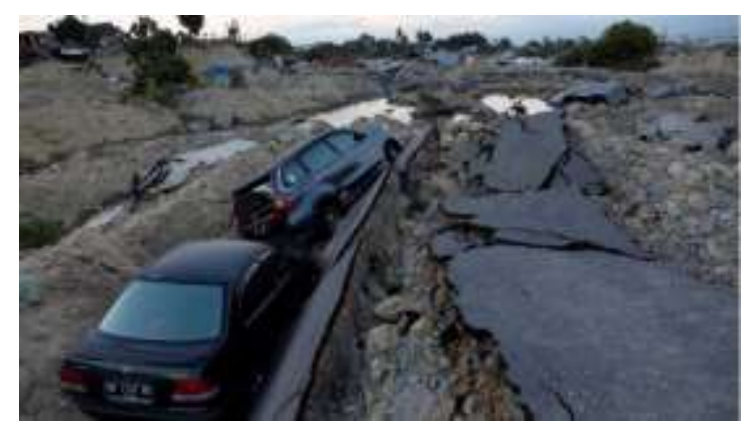

Gambar 13. Liquifaksi di wilayah Balaroa kota Palu menenggelamkan mobil (Sumber: BBC News)

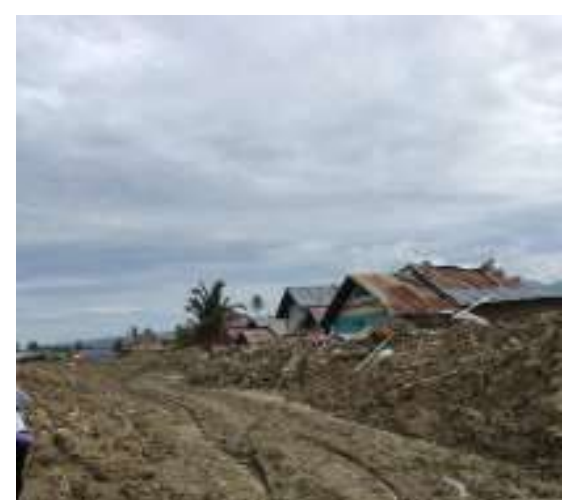




\section{c. Gelombang Tsunami}

Posisi kota Palu yang merupakan teluk mengakibatkan terjadinya gelombang tsunami setinggi $7 \mathrm{~m}$ di Donggala dan 15 $\mathrm{m}$ di Wai pada saat terjadinya gempa tanggal 28 September 2018 yang berpusat di $26 \mathrm{~km}$ utara Donggala dan 80 $\mathrm{km}$ barat laut kota Palu. Dampak dari tsunami tersebut dapat dirasakan sampai radius $1,5 \mathrm{~km}$ dari garis pantai dan $2 \mathrm{~km}$ pada wilayah aliran sungai (Tim Peneliti Unpar, 2019). Pada umumnya tsunami terjadi karena adanya subduksi atau reverse fault yang mengakibatkan perubahan elevasi bumi. Akan tetapi pada Sesar Palu Koro mekanisme gempa bukan subduksi tetapi strike slip (geser) yang seharusnya tidak menimbulkan perubahan volume air laut yang dapat memicu tsunami. Kenyataannya di alam tidak pernah sepenuhnya hanya terjadi geser karena bisa saja ada bagian yang berpindah ke kiri atau ke kanan yang menyebabkan ada bagian sesar yang turun atau menggembung ke atas.

Mekanisme tsunami yang terjadi di teluk Palu lebih disebabkan oleh adanya longsor di pinggir laut. Salah satu indikasinya adalah gelombang yang terjadi bukan gelombang panjang sebab dampaknya hanya terhadap 2-3 bangunan di pantai setelah itu hilang.berdasarkan arahnya tsunami yang diakibatkan reverse fault bentuk gerakan air laut akan lurus menuju daratan sedangkan tsunami yang terjadi di teluk Palu gerakan airnya sangat bervariasi tergantung lokasi kelongsoran tanah. Secara geologi kedalaman teluk Palu mencapai $800 \mathrm{~m}$ dimana bagian pinggir merupakan sedimen pasir dengan kemiringan lereng yang sangat tajam. Hal ini tentunya akan menimbulkan kerawanan terhadap kelongsoran.

Kerusakan akibat tsunami terutama adalah karena gaya dorong dan gaya tarik dari gelombang air yang masuk ke daratan bersamaan dengan material debris yang dibawanya mengapung berupa massa yang besar sehingga terjadi tumbukan yang memberikan dampak kerusakan yang sangat besar. Erosi adalah salah dampak wash out oleh karena itu dapat terlihat dari foto udara banyaknya gerusan yang menyapu material tanah dasar beserta bangunan yang ada diatasnya.

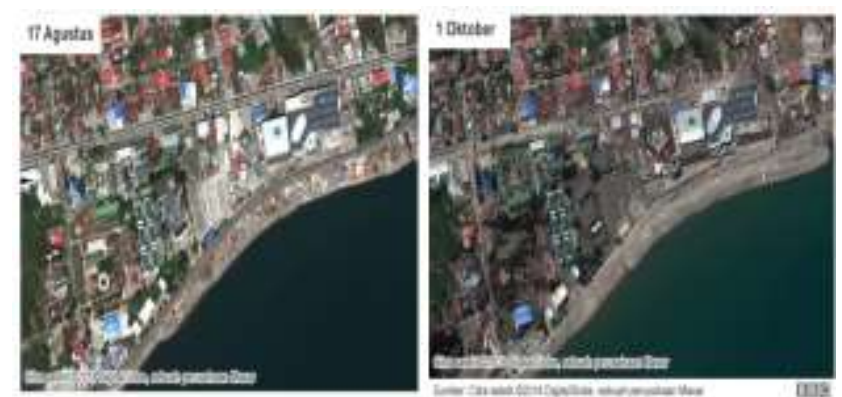

Gambar 14. Palu Sebelum dan Setelah Tsunami (Sumber: BBC News)

\section{d. Kerusakan bangunan Pasca Gempa}

Asessment kerusakan bangunan rumah warga jemaat HKBP Palu yang dilaksanakan oleh TIM PKM FT terhadap 13 rumah tinggal dapat dilihat hasilnya pada Tabel 1 .

Tabel 1. Assesmen kerusakan bangunan rumah 







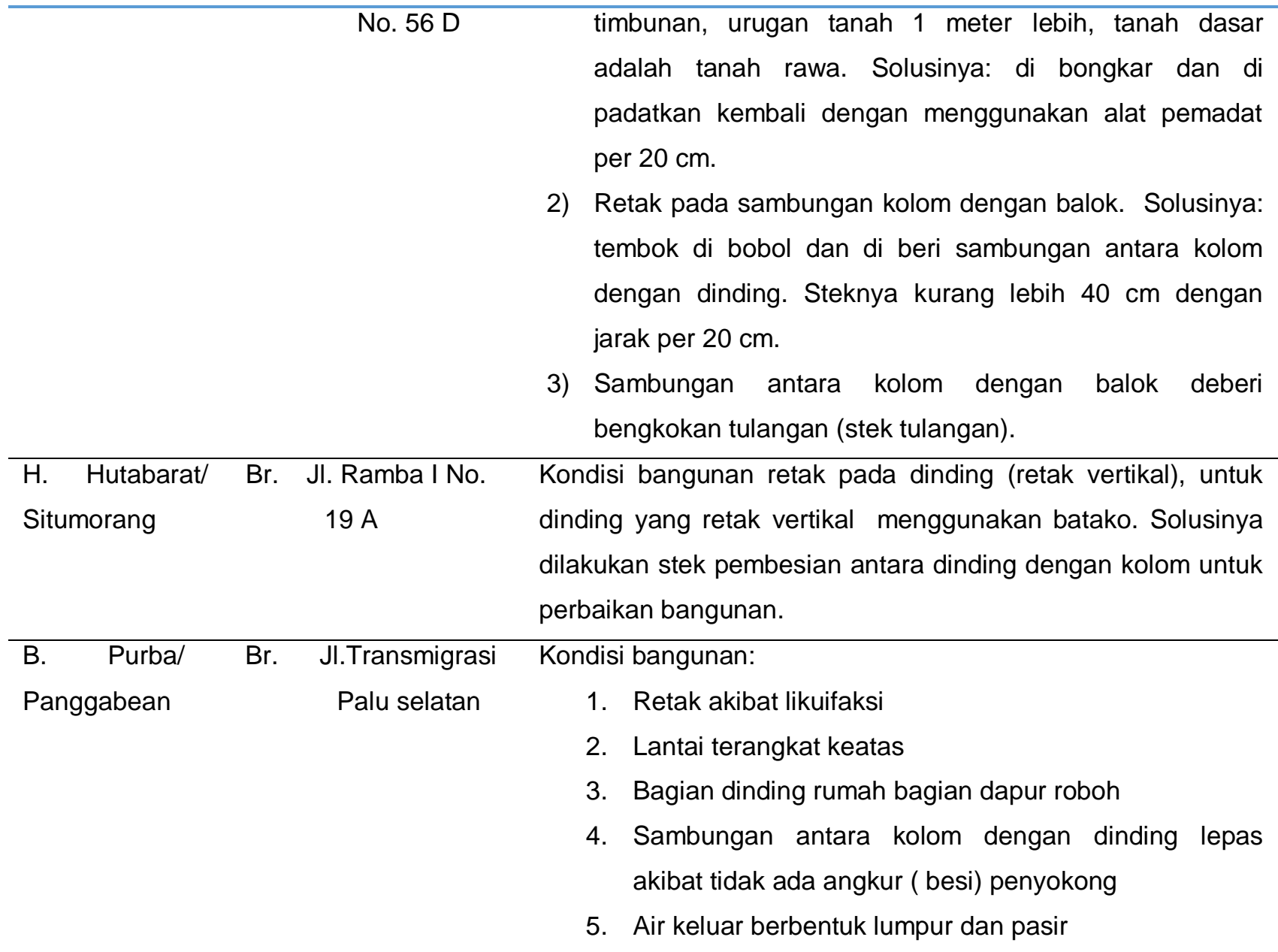

St. M. Silaen

Jl. Kakatua

No.19
Kondisi bangunan:

1. Pagar rumah roboh.

2. Dinding rumah retak, dilakukan perbaikan dengan menggunakan stek besi atau menggunakan kawat nyamuk baru dilakukan pengecoran

3. Dilakukan stek besi untuk sambungan antara kolom dengan dinding.

4. Retak yang terjadi retak vertikal.

\begin{tabular}{lll}
\hline Ny. St Simbolon br. & Btn Tinggede & Kondisi banguan: \\
Tumorang & Palu barat & 1. Layak untuk di tempati. \\
& Sulteng & 2. Buat stek (angkur) untuk kusen pintu dan dinding \\
& & 3. Buat angkur (stek pembesian) antara dinding dengan \\
& & kolom
\end{tabular}

AP. Sinambela br. JI. BTN Pengawu Kondisi bangunan:

Nainggolan Indah blok A1

No. 3 Tatanga

Sulteng
1. Retak pada sambungan kolom dengan dinding dilakukan stek besi per $20 \mathrm{~cm}$,

2. Lakukan pemadatan tanah per $20 \mathrm{~cm}$ agar pemadatan tanah kuat.

3. Untuk daerah kamar mandi dilakukan pemadatan 
tanah (pembongkaran lantai yg rusak dan pemadatan) untuk perbaikan lantai kamar mandi.

\begin{tabular}{|c|c|c|}
\hline $\begin{array}{l}\text { R. Tamba/ br. } \\
\text { Sitohang }\end{array}$ & Jl. Garuda Palu & $\begin{array}{l}\text { Kondisi bangunan retak pada dinding, dilakukan stek besi per } \\
20 \mathrm{~cm} \text { antara dinding dengan kolom untuk perbaikan } \\
\text { (menggunakan kawat nyamuk untuk dinding yg retak). } \\
\text { Dilakukan pengecekan terlebih dahulu untuk dinding yg retak } \\
\text { untuk memastikan kondisi keretakan pada bangunan. }\end{array}$ \\
\hline $\begin{array}{l}\text { J. Simangunsong/ br. } \\
\text { Sitorus }\end{array}$ & $\begin{array}{l}\text { Jl. Garuda } \\
\text { Kecamatan : } \\
\text { Mantikulore (palu } \\
\text { timur) }\end{array}$ & $\begin{array}{l}\text { Kondisi bangunan: } \\
\text { 1. Retak pada sambungan kolom dan dinding depan } \\
\text { rumah untuk solusinya dilakukan stek antara dinding } \\
\text { dengan kolom dengan menggunakan besi setiap jarak } \\
20 \mathrm{~cm} \\
\text { 2. Retak pada dinding dilakukan } \\
\text { 3. Dilakukan pemadatan pada tanah untuk area parkir, } \\
\text { untuk mengatasi kondisi keramik lantai yg pecah dan } \\
\text { retak. }\end{array}$ \\
\hline
\end{tabular}

Nyonya Panggabean/ Jl. Una-una No. Kondisi bangunan:

br Tambunan $\quad 71$ Palu Timur

1. Struktur bangunan bagus, mutu beton untuk ( kolom) baik.

2. Renovasi dilakukan untuk perbaikan teras rumah dan atap.

\begin{tabular}{llr}
\hline $\begin{array}{l}\text { P. Munthe br } \\
\text { sinambela }\end{array}$ & Mantiklore & Kondisi bangunan: \\
Sulteng & 1. Retak pada dinding dilakukan perbaikan dengan \\
& menggunakan kawat nyamuk lalu di plester. \\
& 2. Pada pintu di buat kolom dan balok mencegah \\
& keruntuhan pada pintu. \\
& 3. Di buat stek sambungan antara dinding dengan \\
& kolom.
\end{tabular}

Sumber: Laporan PKM Prodi Teknik Sipil FT UKI, "Investigasi Kerusakan Bangunan Akibat Gempa

Palu 28 September 2018 


\section{KESIMPULAN}

Pada umumnya kerusakan yang terjadi akibat Gempa Palu adalah dipengaruhi beberapa faktor yaitu (1) Karakteristik Goyangan Gempa (intensitas, lama dan muatan frekuensi getaran tanah), (2) Karakteristik Tanah (toppographi, geologi dan kondisi tanah setempat) serta (3) Karakteristik Bangunan (Kekuatan, Kekakuan, Daktilitas dan kekompakan Struktur merespon getaran). Berdasarkan hasil survei yang dilakukan maka penyebab utama kerusakan bangunan akibat gempa di Palu adalah:

a. Goncangan Tanah (getaran gempa)

b. Kegagalan tanah menimbulkan likuifaksi dan longsor bersamaan

c. Gelombang tsunami yang timbul karena sumber gempa di laut

Secara umum para warga warga Palu dan Sekitarnya di Sulawesi Tengah belum sepenuhnya memahami konsep bangunan tahan gempa khususnya untuk rumah tinggal sederhana. Setelah diberikan Penyuluhan dan konsultasi sekaligus assemen ke rumah mereka para warga dapat mengaplikasikan mengerti konsep bangunan tahan gempa secara umum sehingga mereka memiliki keyakinan untuk berencana melakukan kegiatan rekonstruksi rumah tinggalnya. pelaksanaan kegiatan Assesmen ini Perlu di lanjutkan lebih teknis lagi sekaligus implementasi dari Kerjasama FT UKI dengan FT UNTAD. Hal ini perlu untuk pelaksanaan pembangunan rumah mereka dan pengembangan konstruksi bangunan yang lebih besar, mereka masih memerlukan bimbingan lebih lanjut terutama dalam hal pengetahuan teknik struktur bangunan tahan gempanya.

\section{SARAN}

Dalam rangka untuk menjaga warga Palu dan Sekitarnya di Sulteng terkait dengan masalah bangunan tahan gempa, maka saran-saran berikut dapat dijadikan acuan dalam pelaksanaan pembangunan rumah tinggal di masa mendatang:

a) Untuk dapat membuat rumah tinggal yang tahan gempa, pemilihan bahan bangunan yang berkwalitas (mempunyai kekuatan yang tinggi), perlu diperhatikan.

b) Bentuk denah bangunan harus diusahakan memenuhi syarat sebagai bangunan tahan gempa.

c) Pembuatan pondasi bangunan harus disesuaikan dengan kondisi dan kekuatan tanah dimana bangunan tersebut akan didirikan.

d) Struktur bangunan (slof, kolom, dan ring balok) harus dibuat sesuai dengan aturan.

e) Penampatan pintu, jendela, dan ventilasi tidak boleh dilakukan secara sembarangan, artinya jangan sampai memperlemah kekuatan struktur bangunannnya.

f) Penggunaan besi beton (kualitas dan dimensinya) harus sesuai dengan fungsi struktur bangunan tersebut. 
g) Bangunan rumah yang menggunakan rangka atap beton, konstruksi dan dimensinya harus disesuaikan dengan kekuatan struktur bangunan di bawahnya.

h) Teknik penyambungan besi beton harus dilakukan secara benar

\section{UCAPAN TERIMA KASIH}

Ucapan terimakasih kepada Dekan dan Kaprodi FT UNTAD sebagai mitra TIM PKM FT UKI selama melakukan survei dan asessmen kerusakan bangunana di Palu serta pimpinan jemaat gereja HKBP Palu yang memberikan kesempatan untuk melakukan asessmen kerusakan rumah tinggal warga jemaat pasca gempa Palu

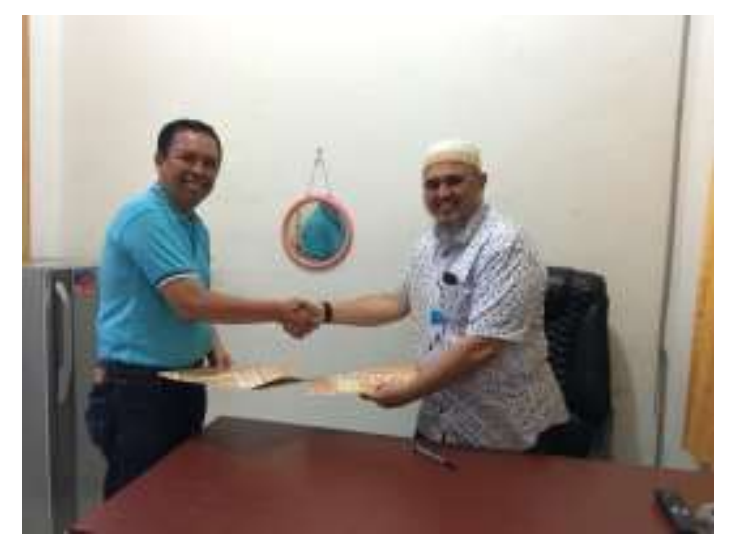

Gambar 15. Penandatangan MoU FT UKI dengan FT UNTAD

\section{REFERENSI}

Badan Geologi Kementrian ESDM, (2018), "Di Balik Pesona Palu Bencana
Melanda Geologi Menata", Cetakan Pertama.

Juwanto, D. (2013). Studi Struktur Geologi Tepi Timur Lembah Palu Kecamatan Palu Timut, dan Tavaili. Kota Palu, Gadjah Mada University.

https://www.bbc.com/indonesia/indonesia$\underline{45721130}$

https://www.bbc.com/indonesia/indonesia$\underline{45716700}$

https://www.bbc.com/indonesia/indonesia$\underline{45708229}$

https://id.wikipedia.org/wiki/Pencairan tana h

http://kaltim.tribunnews.com/2018/10/21/inf o-terkini-gempa-palu-korban-tewas2256-orang-dan-masih-hilang-1309orang-berikut-rinciannya

Laporan PKM Prodi Teknik Sipil FT UKI, "Investigasi Kerusakan Bangunan Akibat Gempa Palu 28 September 2018

Pusat Studi Gempa Nasional, Buku laporan; Peta Sumber dan Bahaya Gempa Indonesia 2017, Pusat Litbang Perumahan dan Pemukiman, PUPR, 2017

Ramadhani, S. (2011). Kondisi Seismisitas dan Dampaknya untuk Kota Palu. JOURNAL TEKNIK SIPIL DAN INFRASTRUKTUR, 1(2).

Tim Peneliti Unpar (2019), Menyelisik Untaian Bencana Palu-Sigi-Donggala, Kajian Gempa Palu Unpar, Bandung 